\title{
Biological evaluation of ethyl acetate extract of Chaetomium cupreum against Ehrlich ascites carcinoma cells in Swiss albino mice
}

\author{
Nazir A. Wani ${ }^{\mathrm{a}}$, Waseem I. Khanday ${ }^{\mathrm{b}}$, Sheihk A. Ali ${ }^{\mathrm{c}}$, Sharmila Tirumale ${ }^{\mathrm{a}}$
}

aDepartment of Microbiology and

Biotechnology, Jnanabharathi Campus, Bangalore University, Bengaluru, Karnataka ${ }^{b} P G$ and Research Centre in Biotechnology, M. G.R. College, Hosur, Tamil Nadu, 'Division of Biotechnology, Indian Institute of Integrative Medicine (CSIR), Sanatnagar, Srinagar, Jammu and Kashmir, India

Correspondence to Sharmila Tirumale, MSc, $\mathrm{PhD}$, Department of Microbiology and Biotechnology, Jnanabharathi Campus, Bangalore University, Bengaluru 560056, Karnataka, India Tel: +91700615 0881; fax: +080 23219295

e-mail: sharmilabub@gmail.com

Received: 13 May 2020

Revised: 18 June 2020

Accepted: 27 July 2020

Published: 30 September 2020

Egyptian Pharmaceutical Journal 2020, 19:274-282

\begin{abstract}
Background
Chaetomium genus is a natural source of different types of secondary metabolites or pigments. These secondary metabolites display a broad spectrum of biological properties including antimicrobial, antioxidant, anti-inflammatory, and anticancer activity.

Objective

The objective of the study was to evaluate the anticancer activity of ethyl acetate extract of Chaetomium cupreum against Ehrlich ascites carcinoma (EAC) cells in Swiss albino mice.

Materials and methods

Methods involved are evaluation of acute toxicity study, tumor induction using EAC cells, estimation of various hematobiochemical parameters, and evaluation of antioxidant enzymes and markers of oxidative stress.

\section{Results}

The ethyl acetate extract of $C$. cupreum-treated EAC-bearing mice at the concentration of $200 \mathrm{mg} / \mathrm{kg}$ body weight (bwt) reduced ascitic fluid volume (1.65 $\pm 0.70 \mathrm{ml})$ and ascitic fluid weight $(1.32 \pm 0.69 \mathrm{~g})$ as compared with ascitic fluid volume $(4.79 \pm 0.52 \mathrm{ml})$ and ascitic fluid weight $(3.93 \pm 0.57 \mathrm{~g})$ in EAC control group. Similarly, the cell apoptosis was higher in EAC-bearing mice treated with standard 5-fluorouracil at $50 \mathrm{mg} / \mathrm{kg}$ bwt $(96.04 \%)$ as compared with treatment with ethyl acetate extract at $50 \mathrm{mg} / \mathrm{kg}$ bwt (21.92\%) followed by $100 \mathrm{mg} / \mathrm{kg}$ bwt (36.63\%) and increased further at $200 \mathrm{mg} / \mathrm{kg}$ bwt $(47.48 \%)$ in treated groups. In hematological estimation, the EAC-bearing mice treated with ethyl acetate extract at $200 \mathrm{mg} / \mathrm{kg}$ bwt showed increased red blood cell count (3.78 $\left.\pm 0.07 \times 10^{6} / \mu \mathrm{l}\right)$ and hemoglobin content $(6.02 \pm 01 \mathrm{~g} / \mathrm{dl})$ and decreased white blood cells count $\left(5.45 \pm 0.01 \times 10^{3} / \mu \mathrm{l}\right)$. In biochemical estimation, ethyl acetate extract treatment in EAC-bearing mice at $200 \mathrm{mg} / \mathrm{kg}$ bwt decreased aspartate aminotransferase activity $(64.10 \pm 0.07 \mathrm{U} / \mathrm{l})$, alanine aminotransferase (55.71 $\pm 0.65 \mathrm{U} / \mathrm{l})$, alkaline phosphatase $(107.04 \pm 0.02 \mathrm{U} / \mathrm{l})$, cholesterol $(124.38 \pm 0.04 \mathrm{mg} /$ $\mathrm{dl})$, and triglycerides $(155.38 \pm 0.04 \mathrm{mg} / \mathrm{dl})$. Similarly, in enzymatic antioxidants and oxidative stress, the ethyl acetate extract-treated EAC-bearing mice at $200 \mathrm{mg} / \mathrm{kg}$ bwt increased superoxide dismutase $(27.10 \pm 0.03 \mathrm{U} / \mathrm{mg}$ protein), catalase $(20.20$ $\pm 0.02 \mathrm{U} / \mathrm{mg}$ protein), and reduced glutathione $(24.04 \pm 0.03 \mathrm{U} / \mathrm{mg}$ protein), whereas decreased glutathione peroxidase $(38.04 \pm 0.07 \mathrm{U} / \mathrm{g}$ hemoglobin) and malondialdehyde content $(170.50 \pm 0.06 \mathrm{nmol} / \mathrm{mg}$ protein) significantly.

Conclusion

The results of the present finding showed that ethyl acetate extract of $C$. cupreum possesses significant anticancer potential.
\end{abstract}

\section{Keywords:}

antioxidant enzymes, Ehrlich tumor, hematobiochemical markers, malondialdehyde, oxidants

Egypt Pharmaceut J 19:274-282

(C) 2020 Egyptian Pharmaceutical Journal

1687-4315

\section{Introduction}

In recent years, a significant development has been made in cancer treatment globally. However, still the development of effective cancer prevention remains the greatest challenges in the area of cancer chemotherapy. Cancer causes most of the morbidity and mortality in the world. The incidence of cancer percentage is increasing globally. The main objective of cancer therapy is to induce death of cancer cells without causing damage or little damage to normal cells [1]. Most of the anticancer drugs are carcinogenic, mutagenic, and expensive. One of the most effective methods of treatment of cancer is chemotherapy. Unfortunately, the presently available chemotherapeutic synthetic anticancer molecules used in the treatment of cancer

This is an open access journal, and articles are distributed under the terms of the Creative Commons Attribution-NonCommercial-ShareAlike 4.0 License, which allows others to remix, tweak, and build upon the work non-commercially, as long as appropriate credit is given and the new creations are licensed under the identical terms. 
have developed drug resistance and cause various adverse effects in patients [2]. Owing to the limitations of synthetic anticancer drugs, there is an urgent need of molecules derived from natural sources such as microorganisms, plants, marine organisms, and fungi for the development of anticancer drugs for the treatment of human cancer [3]. More recently, it was found that tumor cells develop resistance to a single compound easily than multiple compounds. Therefore, treatment of cancer involving combination of drugs is preferred over a single drug treatment, and combination of specific phytochemicals may be more effective than a single compound in preventing against cancer [4].

The phytochemicals from natural source possess various biological activities such as antimicrobial, antioxidant, and anticancer activity $[5,6]$. Approximately $60 \%$ of presently used anticancer drugs are derived from natural source including plants, marine organisms, and microorganisms $[7,8]$. The recent studies have shown that the naturally occurring phytochemicals are more effective with fewer adverse effects than synthetic drugs [9]. The filamentous fungi are known to produce various phytochemicals such as cyclosporine, lovastatin, and penicillin and also a rich resource of novel compounds of therapeutic importance [10].

Chaetomium species belongs to chaetomiaceae family, which are the largest genus of saprophytic ascomycetes and a natural source of different types of metabolites. Since Kunze was the first to establish this genus in 1817 and till now more than 350 Chaetomium species are known [11]. The Chaetomium cupreum was described by Lawrence Marion Ames in 1949 as part of a military effort to identify the organisms responsible for the biodeterioration [12]. In previous studies, methanol extract of C. cupreum-RY202 exhibited in-vitro anticancer activity against $\mathrm{KB}$ cell line having $\mathrm{IC}_{50}-3.25 \mu \mathrm{g} / \mathrm{ml}$ concentration. Further study revealed that isochromophilonol, ochrephilonol, and azaphilones were isolated from $C$. cupreum-RY202, and both the compounds exhibit moderate anticancer against KB and NCI-H187 cell line having $\mathrm{IC}_{50}$ of $9.63-32.42 \mu \mathrm{g} / \mathrm{ml}$ [13]. The $C$. cupreum possess various secondary metabolites with various biological properties [14]. For the present study, Ehrlich ascites carcinoma (EAC) cells were used as the cell line. The Ehrlich tumor is a spontaneous murine mammary adenocarcinoma [15]. The Ehrlich tumor is a rapidly growing carcinoma in all strains of mice. In ascites form in mice, it is used to study the effect of anticancer molecules [16]. To the best of our knowledge, there are no previous reports on the anticancer activity of $C$. cupreum extracts. The purpose of the study was to investigate the anticancer properties of ethyl acetate extract of $C$. cupreum against EAC cells in Swiss albino mice.

\section{Materials and methods \\ Procurement of fungal culture}

The C. cupreum fungus was procured from National Fungal Culture Collection of India (NFCCI), Agharkar Research Institute, Pune, with accession number NFCCI 3117.

\section{Inoculum preparation and extraction}

The C. cupreum was inoculated on potato dextrose agar plates and slants and maintained at $4^{\circ} \mathrm{C}$ for future use. For inoculum preparation, the culture was inoculated into potato dextrose broth and incubated at room temperature for 20 days on a rotary shaker at $120 \mathrm{rpm}$. The extraction involves liquid-liquid method [17]. After incubation, broth was filtered to remove mycelium. Then solvent and broth were taken in equal volume and shaken well for $15 \mathrm{~min}$ in a separating funnel. Then solvent layer was collected, and a crude dried extract powder was obtained.

\section{Animal in-house testing}

Male adult Swiss albino mice weighing between 25 and $30 \mathrm{~g}(n=60)$ were housed in well-ventilated large spacious polypropylene cages under standard conditions of humidity (50-60\%), temperature (30 $\pm 5^{\circ} \mathrm{C}$ ), and light $(12 \mathrm{~h}$ light/dark). Animals were provided with dry pellet rat feed along with tap water ad libitum. Animal experiments were done at the animal facility of KM College of Pharmacy, Madurai, Tamil Nadu, India. The present study involving animals was approved by Institutional Animal Ethical Committee (IAEC) and was conducted according to the guidelines of the committee for the purpose of control and supervision of experiments on animals, with Regd. No.: 661/02/C/CPCSEA/29/09/2017.

\section{Toxicity study of ethyl acetate extract}

The toxicity test in male Swiss albino mice was performed in accordance with the Organization for Economic Co-operation and Development (OECD) guidelines 425 [18]. The Swiss albino mice $(n=6)$ were deprived of food for $18 \mathrm{~h}$ and then administered intraperitoneally $0.25 \mathrm{ml}$ of various doses [250, 500, and $1000 \mathrm{mg} / \mathrm{kg}$ body weight (bwt)] of ethyl acetate extract of $C$. cupreum once only. The toxicity symptoms were recorded for $6,12,24 \mathrm{~h}$, and $48 \mathrm{~h}$, after which time, the number of survival animals was recorded. The 
general behaviors that were observed during acute toxicity study are sedative, hypnosis, convulsion, motor activity, lacrimal secretion, ptosis, change in skin color, and stool consistency.

\section{Experimental design for intraperitoneal dosing of ethyl acetate extract}

Group I: animals were treated with normal saline.

Group II: animals were treated with $250 \mathrm{mg} / \mathrm{kg}$ bwt of ethyl acetate extract.

Group III: animals were treated with $500 \mathrm{mg} / \mathrm{kg}$ bwt of ethyl acetate extract.

Group IV: animals were treated with $1000 \mathrm{mg} / \mathrm{kg}$ bwt of ethyl acetate extract.

\section{Induction of tumor using Ehrlich ascites carcinoma cells}

The EAC cells were procured from Amala Cancer Research Center, Thrissur, Kerala, India, and were maintained and subcultured in Swiss albino mice after every 10th day through intraperitoneally. The cancer formation was done by Jagetia et al. [19] method. After 8 days, ascitic fluid from peritoneal cavity was withdrawn from EAC-bearing mice. The cancer cells were diluted with normal saline and adjusted in a suspension of $1 \times 10^{6}$ cells $/ \mathrm{ml}$. All animals received $100 \mu \mathrm{l} \mathrm{EAC} \mathrm{cells} \mathrm{except} \mathrm{group} \mathrm{I.} \mathrm{After} 2 \mathrm{~h}$, cancerdeveloped animals were divided into six groups, with six animals in each group $(n=6)$.

\section{Experimental design}

Group I (normal control): animals as normal control received with normal saline $(100 \mu 1$ intraperitoneally) from day 1 to 9 .

Group II (EAC control): animals received EAC cells (100 $\mu$ intraperitoneally) from day 1 to 9 .

Group III (standard control): animals received 5fluorouracil at $50 \mathrm{mg} / \mathrm{kg}$ bwt ( $100 \mu \mathrm{l}$ intraperitoneally) from day 1 to 9.

Group IV (EAC+extract): animals received ethyl acetate extract at $50 \mathrm{mg} / \mathrm{kg}$ bwt ( $100 \mu \mathrm{l}$ intraperitoneally) from day 1 to 9.

Group V (EAC+extract): animals received ethyl acetate extract at $100 \mathrm{mg} / \mathrm{kg}$ bwt (100 $\mu \mathrm{l}$ intraperitoneally) from day 1 to 9 .

Group VI (EAC+extract): animals received ethyl acetate extract at $200 \mathrm{mg} / \mathrm{kg}$ bwt (100 $\mu \mathrm{l}$ intraperitoneally) from day 1 to 9 .

\section{Collection of ascitic fluid and blood from animals}

After $24 \mathrm{~h}$ of last dose and $18 \mathrm{~h}$ of fasting (12 days of ethyl acetate extract treatment), the blood was collected in an ethylenediaminetetraacetic acid vial from retro-orbital plexus by sterile capillary for estimation of blood markers. The animals were anesthetized with diethyl ether, and ascitic fluid was collected.

\section{Estimation of ascitic fluid volume, ascitic fluid weight, and cell viability}

The ascitic fluid was measured in graduated centrifuge tube and expressed in milliliters, whereas ascitic fluid weight was measured by weighing ascitic fluid and expressed in grams. The cell viability was measured by diluting ascitic fluid with phosphate buffer saline, and $10 \mu \mathrm{l}$ was mixed with $90 \mu \mathrm{l}$ of Trypan blue dye and then $10 \mu \mathrm{l}$ was placed on hemocytometer. Then viable and dead cells were counted, and percentage viability was calculated as follows:

$\%$ viability $=\frac{\text { Total viable cells }}{\text { Total cells }} \times 100$.

\section{Estimation of hematological parameters in control and experimental animals}

Various hematological parameters such as red blood and white blood cell count and hemoglobin $(\mathrm{Hb})$ were estimated.

\section{Estimation of red blood cell count}

Estimation red blood cell was carried out by using Neubauer hemocytometer counting chambers by Davidson's method [20]. A volume of $0.5 \mathrm{ml}$ of ethylenediaminetetraacetic acid-anticoagulated blood in red blood pipette was diluted to $1: 200$ with Hayem's diluting fluid (mercuric chloride $0.25 \mathrm{~g}$, sodium chloride $0.50 \mathrm{~g}$, sodium sulfate $2.50 \mathrm{~g}$, and distilled water $100 \mathrm{ml}, \mathrm{pH}$ 5.9). After incubation at room temperature for $3 \mathrm{~min}$, the sample was placed on counting chamber and the number of red blood cell per cubic millimeter (cumm) was calculated.

Number of red blood cells/cumm of blood $=\frac{\text { Number of cells } \times \text { dilution factor } \times \text { depth factor }}{\text { Area counted }}$. where the dilution factor is 200 , area counted is $4 \mathrm{~mm}^{2}$ and depth is $0.1 \mathrm{~mm}$.

\section{Estimation of white blood count}

Estimation of white blood cells was carried by using Neubauer hemocytometer counting chamber method [20]. A volume of $0.5 \mathrm{ml}$ of ethylenediaminetetraacetic acid-anticoagulated blood was diluted to 1:20 with Jurks's diluting fluid (glacial acetic acid $2.0 \mathrm{ml}$, gentian violet $1 \%$, distilled water $97 \mathrm{ml}, \mathrm{pH} 2.2$ ). The sample was placed on counting chamber, and 
the number of white blood cells per cumm was calculated as follows:

Number of white blood cells/cumm of blood Number of WBC $\times$ dilution factor $\times$ depth of fluid Area counted

where the dilution factor is 20 , area counted is $4 \mathrm{~mm}^{2}$, and depth is $0.1 \mathrm{~mm}$.

\section{Estimation of hemoglobin}

$\mathrm{The} \mathrm{Hb}$ concentration was measured by the acidhematin method [21]. The graduated $\mathrm{Hb}$ tube was filled with $0.1 \mathrm{~N}$ hydrochloric acid by a dropper. Then blood was filled in the $\mathrm{Hb}$ pipette up to mark $20 \mathrm{~mm}^{3}$ and transferred to graduated $\mathrm{Hb}$ tube containing $0.1 \mathrm{~N}$ hydrochloric acid and further diluted by $0.1 \mathrm{~N}$ hydrochloric acid drop by drop with constant stirring by glass rod till the color matches with that of standard brown glass rod. The results were recorded on the $\mathrm{Hb}$ tube showing concentration of $\mathrm{Hb}$ in grams per deciliter.

\section{Estimation of biochemical parameters in control and experimental animals \\ Aspartate aminotransferase}

The aspartate aminotransferase was estimated by Reitman method [22]. A volume of $4.0 \mathrm{ml}$ of solution 1 (each of $1.0 \mathrm{ml}$ of tris buffer $100 \mathrm{mmol} / \mathrm{l})$, L-aspartate $(300 \mathrm{mmol})$, lactate dehydrogenase $(1.5 \mathrm{U} / \mathrm{ml})$, and malate dehydrogenase $(0.53 \mathrm{U} / \mathrm{ml}))$ was added to $1.0 \mathrm{ml}$ of solution 2 (each of $0.05 \mathrm{ml}$ of $\alpha$-ketoglutarate; $75 \mathrm{mmol} / \mathrm{l})$, and nicotinamide adenine dinucleotide $(0.23 \mathrm{mmol} / \mathrm{l}))$. Then $1 \mathrm{ml}$ of this reaction mixture was added to $100 \mu 1$ of test sample, and sample tubes were incubated for $1 \mathrm{~min}$ at $37^{\circ} \mathrm{C}$, and absorbance was measured at $340 \mathrm{~nm}$. The enzyme activity was expressed as micromole of pyruvate formed $/ \mathrm{mg}$ protein/h.

\section{Alanine aminotransferase}

The alanine aminotransferase was estimated by Reitman method [22]. A volume of $3.0 \mathrm{ml}$ of solution 1 (each of $1.0 \mathrm{ml}$ of tris buffer $100 \mathrm{mmol})$, L-alanine $(500 \mathrm{mmol} / \mathrm{l})$, and lactate dehydrogenase $(1.5 \mathrm{U} / \mathrm{ml})$ was added to $1.0 \mathrm{ml}$ solution 2 (each of $1.0 \mathrm{ml}$ of $\alpha$-ketoglutarate; $15 \mathrm{mmol} / \mathrm{l})$, and nicotinamide adenine dinucleotide $(0.18 \mathrm{mmol} / \mathrm{l})$. Then $1 \mathrm{ml}$ of this reaction mixture was added to $100 \mu \mathrm{l}$ of test sample, and reaction tubes were incubated for $1 \mathrm{~min}$ at $37^{\circ} \mathrm{C}$ and absorbance was read at $340 \mathrm{~nm}$. The enzyme activity was expressed as micromole of pyruvate formed/mg protein/h.

\section{Assay of alkaline phosphatase}

The alkaline phosphatase was estimated by King's method [23]. A volume of $100 \mu \mathrm{l}$ of test sample was mixed well with $0.5 \mathrm{ml}$ enzyme solution, $1.5 \mathrm{ml}$ buffer, and $1.0 \mathrm{ml}$ substrate. After incubation for $15 \mathrm{~min}$ at $37^{\circ} \mathrm{C}, 1.0 \mathrm{ml}$ of Folin's phenol reagent was added and centrifuged for $10 \mathrm{~min}$ at $3000 \mathrm{rpm}$. Then supernatant $(1.0 \mathrm{ml})$ was collected and $1.0 \mathrm{ml}$ substrate, $1.0 \mathrm{ml}$ sodium carbonate $(15 \%)$, and $0.1 \mathrm{ml}$ magnesium chloride were added followed by $37^{\circ} \mathrm{C}$ incubation for $10 \mathrm{~min}$, and absorbance was measured at $640 \mathrm{~nm}$. The enzyme activity in serum was expressed as micromoles of phenol liberated $/ \mathrm{min} / \mathrm{mg}$ of protein.

\section{Estimation of total cholesterol}

The total cholesterol was estimated by Allain method [24]. A volume of $10 \mu 1$ of serum sample was added to $1.0 \mathrm{ml}$ of reagent 1 (tris buffer $100 \mathrm{mM}, \mathrm{pH} \mathrm{7.7}$, sodium cholate $10 \mathrm{mM}$, phenol $6 \mathrm{mM}$, cholesterol hydrolase $33 \mathrm{U} / 1$, cholesterol oxidase $150 \mathrm{U} / 1$, and horseradish peroxidase $200 \mathrm{U} / 1)$. The solution was incubated at $37^{\circ} \mathrm{C}$ for $10 \mathrm{~min}$, and absorbance was measured at $500 \mathrm{~nm}$. The concentration of cholesterol was measured from standard cholesterol calibration curve. The standard cholesterol consists of $100 \mathrm{mg}$ of cholesterol dissolved in $100-\mathrm{ml}$ ice cold acetic acid, and $10 \mathrm{ml}$ was further diluted with $100-\mathrm{ml}$ acetic acid. The cholesterol content was expressed as $\mathrm{mg} / \mathrm{dl}$ serum or $\mathrm{mg} / 100 \mathrm{~g}$ wet tissue.

\section{Estimation of triglycerides}

The triglyceride content was estimated by Werner method [25]. A volume of $10 \mu 1$ of test sample was incubated at $37^{\circ} \mathrm{C}$ for $5 \mathrm{~min}$ and added to $1.0 \mathrm{ml}$ of reagent 1 (tris- $\mathrm{HCl}$ buffer $100 \mathrm{mM}, \mathrm{pH} 7.8$, glycerophosphate oxidase $2000 \mathrm{U} / 1$, lipase $1000 \mathrm{U} / 1$, glycerol kinase $800 \mathrm{U} / 1$, peroxidase $150 \mathrm{U} / 1$, sodium azide $0.1 \%$, magnesium chloride $17 \mathrm{mM}$, 4aminoantipyrene $0.4 \mathrm{mM}$, ATP $0.55 \mathrm{mM}$, and 3hydroxyl-2,4,6-tribromobenzoic acid $1.6 \mathrm{mM}$ ), and absorbance was measured at $540 \mathrm{~nm}$. The triglyceride content was expressed as $\mathrm{mg} / \mathrm{dl}$.

\section{Estimation of enzymatic antioxidants and markers of oxidative stress in control and experimental animals Estimation of superoxide dismutase}

The superoxide dismutase was estimated by Misra's method [26]. A volume of 1.0-ml plasma in potassium phosphate buffer was mixed with $1.0 \mathrm{ml}$ of sodium carbonate $(50 \mathrm{mM}), \quad 0.2 \mathrm{ml}$ of hydroxylamine hydrochloride $(0.1 \mathrm{mM})$, and $0.4 \mathrm{ml}$ of nitroblue tetrazolium $(75 \mathrm{mM})$. The reaction mixture was mixed well, and development of blue color was monitored at $560 \mathrm{~nm}$ spectrometrically. The 
superoxide dismutase activity was expressed as $\mathrm{U} / \mathrm{mg}$ protein.

\section{Estimation of catalase}

The catalase was estimated by Aebi method [27]. A volume of $0.1 \mathrm{ml}$ of plasma was mixed well with $1.0 \mathrm{ml}$ of hydrogen peroxide $(0.5 \mathrm{mM})$ and $1.9 \mathrm{ml}$ pf phosphate buffer $(10 \mathrm{mM})$. The absorbance was read at $240 \mathrm{~nm}$, keeping 1-min interval for $3 \mathrm{~min}$. The enzyme activity was expressed as micromoles hydrogen peroxide consumed $/ \mathrm{min} / \mathrm{mg}$ protein.

\section{Estimation of reduced glutathione}

The reduced glutathione was estimated by Ellman method [28]. A 1.0-ml test sample was added to $1.0 \mathrm{ml}$ of $20 \%$ trichloroacetic acid, which contains $1 \mathrm{mM}$ ethylenediaminetetraacetic acid for precipitating proteins. The solution was incubated for $5 \mathrm{~min}$ at room temperature and then centrifuged for $10 \mathrm{~min}$ at $2000 \mathrm{rpm}$. In $200 \mu \mathrm{l}$ of supernatant, $1.8 \mathrm{ml}$ of Ellman's reagent $(0.1 \mathrm{mM}, 5,50$-dithiobis-2nitrobenzoic acid) was added, and absorbance was measured at $412 \mathrm{~nm}$. The reduced glutathione content was calculated from standard graph from known reduced glutathione. The reduced glutathione was expressed as nanomoles/mg protein or $\mathrm{U} / \mathrm{mg}$ protein.

\section{Estimation of glutathione peroxidase}

The glutathione peroxidase activity was estimated by Hafemann et al. [29]. Volumes of $0.1 \mathrm{ml}$ of $5 \mathrm{mM}$ reduced glutathione, $0.02 \mathrm{ml}$ of plasma, $0.1 \mathrm{ml}$ of $1.25 \mathrm{mM} \mathrm{H} \mathrm{H}_{2} \mathrm{O}_{2}, \quad 0.1 \mathrm{ml}$ of $25 \mathrm{mM}$ sodium azide, and $1.0 \mathrm{ml}$ of $0.05 \mathrm{mM}$ phosphate buffer were incubated for $10 \mathrm{~min}$ for $37^{\circ} \mathrm{C}$. The reaction was terminated by adding $2 \mathrm{ml}$ of $1.65 \%$ of hydrogen phosphite and centrifuged at $1500 \mathrm{rpm}$ for $10 \mathrm{~min}$. Then $2.0 \mathrm{ml}$ of supernatant was added to $2 \mathrm{ml}$ of $0.4 \mathrm{M}$ disodium hydrogen phosphate and $1 \mathrm{ml}$ of $1 \mathrm{mM}$ Ellman's regent (DTNB) and incubated at $37^{\circ} \mathrm{C}$ for $10 \mathrm{~min}$, and absorbance was measured at $412 \mathrm{~nm}$. The results are expressed as $\mathrm{U} / \mathrm{g} \mathrm{Hb}$.

\section{Estimation of malondialdehyde}

The malondialdehyde (MDA) content is estimated by Draper method [30]. A volume of $0.5 \mathrm{ml}$ of test sample was added to $1 \mathrm{ml}$ of trichloroacetic acid. This mixture was centrifuged at $4000 \mathrm{rpm}$ for $10 \mathrm{~min}$. Then $0.5 \mathrm{ml}$ of supernatant was mixed with $1.0 \mathrm{ml}$ of $0.67 \%$ thiobarbituric acid reagent followed by incubation for $15 \mathrm{~min}$ at $95^{\circ} \mathrm{C}$, and absorbance was read at $532 \mathrm{~nm}$. The MDA was expressed as nanomoles of $\mathrm{MDA} / \mathrm{mg}$ protein.

\section{Statistical analysis}

The two-way analysis of variance followed by Tukey's multiple comparison tests with graph pad prism 6 software (Graphpad Software, Inc., United states) was used.

\section{Results}

\section{Toxicity study of ethyl acetate extract}

The intraperitoneal toxicity test was investigated to assess the therapeutic index, which is the ratio of lethal dose and pharmacologically effective dose for the survival and treatment of mice. The behavior of the animals was closely monitored for 6, 12, $24 \mathrm{~h}$, till $48 \mathrm{~h}$. It was found that ethyl acetate extract of $C$. cupreum did not induce behavioral changes such as hypnosis, convulsion lacrimal secretion, ptosis, change in skin color, stool consistency, diarrhea, locomotor ataxia, weight loss, and mortality in mice during the $48 \mathrm{~h}$ of observation. However, a mild sedation was observed (Table 1).

\section{Ascitic fluid volume, ascitic fluid weight, cell viability $(\%)$, and cell death (\%) in control and experimental animals}

The anticancer activity of ethyl acetate extract of $C$. cupreum against EAC cancer-bearing mice was evaluated by measuring the ascitic fluid volume, ascitic fluid weight, and cell viability. From the results, the ascitic fluid volume $(4.79 \pm 0.52 \mathrm{ml})$ and ascitic fluid weight $(3.93 \pm 0.57 \mathrm{~g})$ increased significantly in EAC control group (Table 2). The treatment of EAC-bearing mice with ethyl acetate extract of $C$. cupreum reduced ascitic fluid volume to $2.78 \pm 0.44 \mathrm{ml}$ and ascitic fluid weight to $2.81 \pm 0.27 \mathrm{~g}$ at $50 \mathrm{mg} / \mathrm{kg}$ bwt, whereas standard 5-fluorouracil decreased ascitic fluid volume to $0.57 \pm 0.22 \mathrm{ml}$ and ascitic fluid weight to $0.44 \pm 0.22 \mathrm{~g}$ at $50 \mathrm{mg} / \mathrm{kg}$ bwt. The cell count (\% viable) and cell death (\% nonviable) were evaluated by trypan blue assay. The cell viability count was higher in EAC control group (98.02\%) than

Table 1 Acute toxicity test of ethyl acetate extract of Chaetomium cupreum

\begin{tabular}{lcc}
\hline Serial numbers & General behavior & Ethyl acetate extract \\
\hline 1 & Sedative & + \\
2 & Hypnosis & - \\
3 & Convulsion & - \\
4 & Ptosis & - \\
5 & Motor activity & - \\
6 & Change in skin color & - \\
7 & Lacrimal secretion & - \\
8 & Diarrhea & - \\
9 & Weight loss & - \\
10 & Mortality & - \\
\hline
\end{tabular}

+, positive;-, negative. 
Table 2 Effect of ethyl acetate extract of Chaetomium cupreum on ascitic fluid volume, ascitic fluid weight, viability (\%), and inhibition (\%) between Ehrlich ascites carcinoma control and experimental groups.

\begin{tabular}{|c|c|c|c|c|}
\hline \multirow[b]{2}{*}{ Treatment } & \multicolumn{4}{|c|}{12 days treatment } \\
\hline & Volume of ascitic fluid (ml) & Weight of ascitic fluid (g) & $\%$ cell viability & $\%$ cell death \\
\hline EAC control & $4.79 \pm 0.52^{\mathrm{a}}$ & $3.93 \pm 0.57^{\mathrm{a}}$ & $98.02 \pm 0.20^{\mathrm{a}}$ & $2 \pm 0.001^{a}$ \\
\hline $\mathrm{EAC}+5$-fluorouracil (50 mg/kg bwt) & $0.57 \pm 0.22^{\mathrm{b \#}}$ & $0.44 \pm 0.22^{\mathrm{b \#}}$ & $3.96 \pm 0.13^{\mathrm{b} \#}$ & $96.04 \pm 0.53^{\mathrm{b} \#}$ \\
\hline EAC+ethyl acetate extract $(50 \mathrm{mg} / \mathrm{kg}$ bwt $)$ & $2.78 \pm 0.44^{\mathrm{c \# A}}$ & $2.81 \pm 0.27^{\mathrm{C \# A}}$ & $78.08 \pm 0.37^{\mathrm{c \# A}}$ & $21.92 \pm 0.17^{\mathrm{c \# A}}$ \\
\hline EAC+ethyl acetate extract $(100 \mathrm{mg} / \mathrm{kg}$ bwt $)$ & $1.87 \pm 0.37 \mathrm{~dB}$ & $1.02 \pm 0.34^{\mathrm{d \# B}}$ & $63.37 \pm 0.54^{\mathrm{d} \# \mathrm{~B}}$ & $36.63 \pm 0.27^{\mathrm{d} \# \mathrm{~B}}$ \\
\hline EAC+ethyl acetate extract $(200 \mathrm{mg} / \mathrm{kg}$ bwt $)$ & $1.65 \pm 0.70^{\mathrm{eCB}}$ & $1.32 \pm 0.69^{\mathrm{e} C \mathrm{CB}}$ & $52.52 \pm 0.21^{\mathrm{e \# C}}$ & $47.48 \pm 0.01^{\mathrm{e \# C}}$ \\
\hline
\end{tabular}

Values are represented as mean \pm SD $(n=3)$. bwt, body weight; EAC, Ehrlich ascites carcinoma. Significance difference between the untreated control and experimental groups are represented in lower case and between the standard fluorouracil and experimental groups in hashes. Significance difference between the concentrations is represented in upper case. Those not sharing the same letter are significantly different at $P$ value less than 0.05 .

Table 3 Effect of ethyl acetate extract of Chaetomium cupreum on hematological parameters between Ehrlich ascites carcinoma control and experimental groups

\begin{tabular}{lccc}
\hline Treatment & RBC count (cells $\left.\times 10^{6} / \mu \mathrm{l}\right)$ & Total WBC $\left(\right.$ cells $\left.\times 10^{3} / \mu \mathrm{l}\right)$ & $\mathrm{Hb}(\mathrm{g} / \mathrm{dl})$ \\
\hline Untreated & $5.95 \pm 0.08^{\mathrm{a}}$ & $4.85 \pm 0.47^{\mathrm{a}}$ & $10.75 \pm 0.10^{\mathrm{a}}$ \\
EAC control & $2.50 \pm 1.2^{\mathrm{b}}$ & $8 \pm 1.1^{\mathrm{b}}$ & $5.10 \pm 1.0^{\mathrm{b}}$ \\
EAC+5-fluorouracil $(50 \mathrm{mg} / \mathrm{kg}$ bwt) & $4.43 \pm 0.07^{\mathrm{C \#}}$ & $5.42 \pm 1.08^{\mathrm{a \#}}$ & $9.11 \pm 0.03^{\mathrm{c \#}}$ \\
EAC + ethyl acetate extract $(50 \mathrm{mg} / \mathrm{kg} \mathrm{bwt)}$ & $2.10 \pm 0.06^{\mathrm{d \# A}}$ & $6.91 \pm 0.78^{\mathrm{c \# A}}$ & $3.45 \pm 0.07^{\mathrm{d \# A}}$ \\
EAC+ethyl acetate extract $(100 \mathrm{mg} / \mathrm{kg} \mathrm{bwt)}$ & $3.08 \pm 0.07^{\mathrm{e \# A}}$ & $6.71 \pm 0.65^{\mathrm{d \# A}}$ & $5.04 \pm 0.04^{\mathrm{e \# B}}$ \\
EAC+ethyl acetate extract $(200 \mathrm{mg} / \mathrm{kg}$ bwt) & $3.78 \pm 0.07^{\mathrm{fBA}}$ & $5.45 \pm 0.01^{\mathrm{aB}}$ & $6.02 \pm 0.1^{\mathrm{f \# C}}$ \\
\hline
\end{tabular}

Values are represented as mean \pm SD $(n=3)$. bwt, body weight; EAC, Ehrlich ascites carcinoma; Hb, hemoglobin; RBC, red blood cells count; WBC, white blood count. Significance difference between the untreated control and experimental groups is represented in lower case and between the standard fluorouracil and experimental groups in hashes. Significance difference between the concentrations is represented in upper case. Those not sharing the same letter are significantly different at $P$ value less than 0.05 .

the standard 5-fluorouracil-treated group (3.96\%). However, ethyl acetate extract treatment reduced cell viability count to $78.08 \%$ at $50 \mathrm{mg} / \mathrm{kg}$ bwt, followed by $63.37 \%$ at $100 \mathrm{mg} / \mathrm{kg}$ bwt, and $52.52 \%$ at $200 \mathrm{mg} / \mathrm{kg}$ bwt in the treated groups. Similarly, the cell death in ethyl acetate extract treatment was $21.92 \%$ at $50 \mathrm{mg} / \mathrm{kg}$ bwt, followed by $36.63 \%$ at $100 \mathrm{mg} / \mathrm{kg}$ bwt and $47.48 \%$ at $200 \mathrm{mg} / \mathrm{kg}$ bwt in treated groups. However, cell death was $96.04 \%$ in standard 5-fluorouracil at $50 \mathrm{mg} / \mathrm{kg}$ bwt (Table 2).

\section{Hematological parameters in control and experimental animals}

All hematological parameters were evaluated in treated and control animals and are presented in Table 3. In EAC control group, red blood cells count $(2.50$ $\left.\pm 1.2 \times 10^{6} / \mu \mathrm{l}\right)$ and $\mathrm{Hb}$ content $(5.10 \pm 1.0 \mathrm{~g} / \mathrm{dl})$ decreased, whereas white blood count increased (8 $\pm 1.1 \times 10^{3} / \mu 1$ ) compared with normal group. Similarly, ethyl acetate treatment at $50 \mathrm{mg} / \mathrm{kg}$ bwt increased red blood cells count to $2.10 \pm 0.06 \times 10^{6} / \mu 1$ and $\mathrm{Hb}$ content to $3.45 \pm 0.07 \mathrm{~g} / \mathrm{dl}$, whereas decreased white blood count to $6.91 \pm 0.78 \times 10^{3} / \mu 1$ in EAC-bearing mice. However, the 5 -fluorouracil treatment at $50 \mathrm{mg} / \mathrm{kg}$ bwt increased red blood cells count to $4.43 \pm 0.07 \times 10^{6} / \mu 1$ and $\mathrm{Hb}$ content to $9.11 \pm 0.03 \mathrm{~g} / \mathrm{dl}$, whereas reduced the white blood count to $5.42 \pm 1.08 \times 10^{3} / \mu 1$ in EAC-bearing mice significantly (Table 3 ).

\section{Biochemical parameters in control and experimental animals}

In the results, treatment with ethyl acetate extract of C. cupreum at $50 \mathrm{mg} / \mathrm{kg}$ bwt decreased aspartate aminotransferase activity $(81.50 \pm 0.06 \mathrm{U} / 1)$, alanine aminotransferase $(66.91 \pm 0.78 \mathrm{U} / 1)$, alkaline phosphatase $(123.45 \pm 0.07 \mathrm{U} / 1)$, cholesterol $(141.01$ $\pm 0.04 \mathrm{mg} / \mathrm{dl}$ ), and triglycerides $(176.01 \pm 0.04 \mathrm{mg} / \mathrm{dl})$ significantly. However, standard 5-fluorouracil at $50 \mathrm{mg} / \mathrm{kg}$ bwt decreased aspartate aminotransferase $(50.43 \pm 0.07 \mathrm{U} / 1), \quad$ alkaline phosphatase (40.23 $\pm 1.08 \mathrm{U} / \mathrm{l})$, alanine aminotransferase $(70.11 \pm 0.03 \mathrm{U} /$ 1), cholesterol $(112.09 \pm 0.07 \mathrm{mg} / \mathrm{dl})$, and triglycerides $(145.09 \pm 0.07 \mathrm{mg} / \mathrm{dl})$ significantly $(P=0.05)$ (Table 4$)$.

\section{Enzymatic parameters in control and experimental animals}

The results showed that all enzymatic antioxidant and oxidative stress markers increased in EAC-bearing mice compared with normal group (Table 5). The ethyl acetate extract of $C$. cupreum treatment at $50 \mathrm{mg} / \mathrm{kg}$ bwt increased superoxide dismutase $(15.50$ $\pm 0.06 \mathrm{U} / \mathrm{mg}$ protein), catalase $\left(9.91 \pm 0.78 \mu \mathrm{mol} \mathrm{H}_{2} \mathrm{O}_{2}\right.$ consumed $/ \mathrm{min} / \mathrm{mg}$ protein), and reduced glutathione $(11.45 \pm 0.07 \mathrm{U} / \mathrm{mg}$ protein), whereas decreased glutathione peroxidase $(54.45 \pm 0.10 \mathrm{U} / \mathrm{g} \mathrm{Hb})$ and MDA (230.01 $\pm 0.04 \mathrm{nmol} / \mathrm{mg}$ protein) significantly $(P=0.05)$ in EAC-bearing mice. However, standard 5 -fluorouracil treatment at $50 \mathrm{mg} / \mathrm{kg}$ bwt increased 
Table 4 Effect of ethyl acetate of Chaetomium cupreum on serum biochemical parameters between Ehrlich ascites carcinoma control and experimental groups

\begin{tabular}{lccccc}
\hline Treatment & AST (U/l) & ALT (U/l) & ALP (U/l) & Cholesterol (mg/dl) & Triglycerides (mg/dl) \\
\hline Untreated & $53.95 \pm 0.08^{\mathrm{a}}$ & $41.85 \pm 0.47^{\mathrm{a}}$ & $92.75 \pm 0.10^{\mathrm{a}}$ & $105 \pm 0.02^{\mathrm{a}}$ & $125 \pm 0.02^{\mathrm{a}}$ \\
EAC control & $93.50 \pm 1.2^{\mathrm{b}}$ & $70 \pm 0.2^{\mathrm{b}}$ & $130.10 \pm 1.0^{\mathrm{b}}$ & $150.86 \pm 0.01^{\mathrm{b}}$ & $190.86 \pm 0.01^{\mathrm{b}}$ \\
EAC+5-fluorouracil (50 mg/kg bwt) & $50.43 \pm 0.07^{\mathrm{c \#}}$ & $40.23 \pm 1.08^{\mathrm{c \#}}$ & $70.11 \pm 0.03^{\mathrm{c \#}}$ & $112.09 \pm 0.07^{\mathrm{c \#}}$ & $132.09 \pm 0.07^{\mathrm{c \#}}$ \\
EAC+ethyl acetate extract (50 mg/kg bwt) & $81.50 \pm 0.06^{\mathrm{d \# A}}$ & $66.91 \pm 0.78^{\mathrm{d \# A}}$ & $123.45 \pm 0.07^{\mathrm{d \# A}}$ & $141.01 \pm 0.04^{\mathrm{d \# A}}$ & $176.01 \pm 0.04^{\mathrm{d \# A}}$ \\
EAC+ethyl acetate extract (100 mg/kg bwt) & $75.80 \pm 0.07^{\mathrm{e \# B}}$ & $61.71 \pm 0.65^{\mathrm{e \# B}}$ & $115.04 \pm 0.04^{\mathrm{e \# B}}$ & $135.38 \pm 0.04^{\mathrm{e \# B}}$ & $165.38 \pm 0.04^{\mathrm{e \# B}}$ \\
EAC+ethyl acetate extract (200 mg/kg bwt) & $64.10 \pm 0.07^{\mathrm{f \# C}}$ & $55.71 \pm 0.65^{\mathrm{f \# C}}$ & $107.04 \pm 0.02^{\mathrm{f \# C}}$ & $124.38 \pm 0.04^{\mathrm{f \# C}}$ & $155.38 \pm 0.04^{\mathrm{f \# C}}$ \\
\hline
\end{tabular}

Values are represented as mean \pm SD $(n=3)$. ALP, alkaline phosphatase; ALT, alanine aminotransferase; AST, Aspartate aminotransferase; bwt, body weight; EAC, Ehrlich ascites carcinoma. Significance difference between the untreated control and experimental groups is represented in lower case and between the standard fluorouracil and experimental groups in hashes. Significance difference between the concentrations is represented in upper case. Those not sharing the same letter are significantly different at $P$ value less than 0.05 .

Table 5 Effect of ethyl acetate extract of Chaetomium cupreum on the enzymatic antioxidants and markers of oxidative stress between Ehrlich ascites carcinoma control and experimental groups

\begin{tabular}{|c|c|c|c|c|c|}
\hline Treatment & $\begin{array}{c}\text { Superoxide } \\
\text { dismutase (units/mg } \\
\text { protein) }\end{array}$ & $\begin{array}{c}\text { Catalase }\left(\mu \mathrm{mol} \mathrm{H}_{2} \mathrm{O}_{2}\right. \\
\text { consumed } / \mathrm{min} / \mathrm{mg} \\
\text { protein })\end{array}$ & $\begin{array}{c}\text { Reduced } \\
\text { glutathione (U/mg } \\
\text { protein) }\end{array}$ & $\begin{array}{c}\text { Glutathione } \\
\text { peroxidase }(\mathrm{U} / \mathrm{g} \\
\mathrm{Hb})\end{array}$ & $\begin{array}{l}\text { Malondialdehyde } \\
\text { (nmol/mg protein) }\end{array}$ \\
\hline Untreated & $35.95 \pm 0.08^{a}$ & $28.85 \pm 0.47^{a}$ & $34.75 \pm 0.10^{\mathrm{a}}$ & $22.75 \pm 0.10^{\mathrm{a}}$ & $130.78 \pm 0.02^{\mathrm{a}}$ \\
\hline EAC control & $10.50 \pm 1.2^{b}$ & $8 \pm 1.1^{b}$ & $15.10 \pm 1.0^{b}$ & $60.10 \pm 1.0^{\mathrm{b}}$ & 258. $86 \pm 0.01^{b}$ \\
\hline $\begin{array}{l}\text { EAC+5-fluorouracil } \\
\text { (50 mg/kg bwt) }\end{array}$ & $30.43 \pm 0.07^{\text {c\# }}$ & $25.42 \pm 1.08^{\mathrm{c \#}}$ & $27.11 \pm 0.03^{\mathrm{c \#}}$ & $35.11 \pm 0.02^{\mathrm{c \#}}$ & $160.09 \pm 0.07^{\mathrm{c \#}}$ \\
\hline $\begin{array}{l}\text { EAC+extract }(50 \mathrm{mg} / \mathrm{kg} \\
\text { bwt) }\end{array}$ & $15.50 \pm 0.06^{\mathrm{d} \# \mathrm{~A}}$ & $9.91 \pm 0.78^{\mathrm{dHA}}$ & $11.45 \pm 0.07^{\mathrm{d \# A}}$ & $54.45 \pm 0.10^{\mathrm{d} \# \mathrm{~A}}$ & $230.01 \pm 0.04^{\mathrm{d} \# \mathrm{~A}}$ \\
\hline $\begin{array}{l}\text { EAC+extract }(100 \mathrm{mg} / \\
\mathrm{kg} \text { bwt })\end{array}$ & $21.780 \pm 0.07^{\text {e\#B }}$ & $15.71 \pm 0.65^{\mathrm{e \# B}}$ & $19.04 \pm 0.04^{\mathrm{e \# B}}$ & $46.04 \pm 0.12^{\mathrm{e} B \mathrm{~B}}$ & $196.38 \pm 0.04^{\mathrm{e}}$ \\
\hline $\begin{array}{l}\text { EAC+ethyl acetate } \\
\text { extract }(200 \mathrm{mg} / \mathrm{kg} \\
\text { bwt) }\end{array}$ & $27.10 \pm 0.03^{\mathrm{f} \# \mathrm{C}}$ & $20.20 \pm 0.02^{\mathrm{f \# C}}$ & $24.04 \pm 0.03^{\mathrm{f \# C}}$ & $38.04 \pm 0.07^{f \# C}$ & $170.50 \pm 0.06^{f \# C}$ \\
\hline
\end{tabular}

Values are represented as mean \pm SD $(n=3)$. bwt, body weight; EAC, Ehrlich ascites carcinoma; Hb, hemoglobin. Significance difference between the untreated control and experimental groups is represented in lower case and between the standard fluorouracil and experimental groups in hashes. Significance difference between the concentrations is represented in upper case. Those not sharing the same letter are significantly different at $P$ value less than 0.05 .

superoxide dismutase $(30.43 \pm 0.07 \mathrm{U} / \mathrm{mg}$ protein $)$, catalase $\left(25.42 \pm 1.08 \mu \mathrm{mol} \mathrm{H}_{2} \mathrm{O}_{2}\right.$ consumed $/ \mathrm{min} / \mathrm{mg}$ protein), and reduced glutathione $(27.11 \pm 0.03 \mathrm{U} / \mathrm{mg}$ protein), whereas decreased glutathione peroxidase $(35.11 \pm 0.02 \mathrm{U} / \mathrm{g} \mathrm{Hb})$ and MDA $(160.09 \pm 0.07 \mathrm{nmol} /$ $\mathrm{mg}$ protein) in EAC mice significantly $(P=0.05)$ (Table 5).

\section{Discussion}

Previous reports by the same authors demonstrated that extracts of $C$. cupreum are rich in various phytochemicals such as flavonoids, carbohydrates, saponins, tannins, glycosides, phytosterol, phenolic terpenoids, azaphilones, and coumarins compounds [17]. Another study reported that extracts of $C$. cupreum have antioxidant potential because of various phytochemicals present [31]. Based on these observations, anticancer activity of ethyl acetate extract of $C$. cupreum extract against EAC cells was evaluated. The hematological parameters, serum biochemical parameters, and antioxidant enzymes are considered as important tools for the evaluation of physiological and health status of the organism as well as diagnosis and disease treatment. These parameters indicate the changes in the metabolism of the organism [32]. The parameters such as red blood cells and white blood cells and $\mathrm{Hb}$ content are used to analyze blood diagnosis. Owing to the clinical importance of various biochemical parameters such as aspartate aminotransferase, alanine aminotransferase, alkaline phosphate, total cholesterol, and triglycerides, they are used for monitoring and are used as diagnostic tools in patients with diseases in liver, pancreas, kidney, and blood. All these biochemical parameters are used for disease detection all over the world, as well as by International Federation of Clinical Chemistry (IFCC) and the Scandinavian Committee on Enzymes (SCE) [33-35]. Moreover, during overproduction of reactive oxygen species, the antioxidant enzymes such as catalase, superoxide dismutase, glutathione peroxidase, and reduced glutathione provide the measurement free radicals as well as about the oxidative damage caused by the free radical in the cell $[36,37]$. 
The toxicity report of the present study proved that ethyl acetate extract of $C$. cupreum did not provoke any pharmacological and behavioral changes. Thus, ethyl acetate extract of C. cupreum appeared safe for preclinical trials. At $50 \mathrm{mg} / \mathrm{kg}$ bwt, ethyl acetate extract of C. cupreum decreased cancer volume, cancer weight, and cancer cell viability. At $50 \mathrm{mg} / \mathrm{kg}$ bwt, ethyl acetate extract showed $21.92 \%$ cell death whereas 5-fluorouracil showed $96.04 \%$ cell death. The hemolysis results in red blood cell or $\mathrm{Hb}$ count reduction and causes anemia [38]. However, ethyl acetate extract treatment replenishes red blood cells and $\mathrm{Hb}$ count toward normal level in a dose-dependent manner. Thus, it indicates that ethyl acetate extract of C. cupreum protects cell surface and thus helps in maintaining normal hemopoietic system. The elevated levels of biochemical parameters such as aspartate aminotransferase, alanine aminotransferase, alkaline phosphatase, cholesterol, and triglycerides indicate impaired liver function owing to injection of EAC cells [39]. The treatment of EAC-bearing mice with ethyl acetate extract decreased the level of biochemical parameters in ascitic cancer in a dosedependent manner, which suggests that phytochemicals present in C. cupreum have the capacity to stabilize the plasma membrane of a cell.

The reduced function of enzymatic antioxidants will result in overproduction of free radicals which is detrimental to cell membrane integrity. The superoxide dismutase and catalase catalyze the dismutation of superoxide anion radical to hydrogen peroxide. Then catalase converts hydrogen peroxide into oxygen and water [40]. Previous studies have presented evidence that reduced glutathione has chemoprotective action, and its deficiency is a risk to cells to oxidative damage [41]. Another study demonstrated that $C$. cupreum extracts contain high levels of different types of phytochemicals [17]. These phytochemicals donate electrons or atoms to free radicals and thus also repair the enzymatic antioxidants of a cell. Similarly, treatment of EACbearing mice with ethyl acetate extract to different doses increases the enzymatic antioxidants to normal level in a dose-dependent manner. Oxidative stress damages lipids and induce lipid peroxidation. MDA is a product produced owing to lipid peroxidation and is used as a marker of cell membrane injury [42]. The MDA is a potentially important contributor to DNA damage and mutations, which it generates endogenously through lipid peroxidation [43]. Thus, MDA can be used as main marker for diagnosis for tumors. The level of lipid peroxides in EAC cellbearing mice was increased and was decreased with ethyl acetate extract treatment in treated groups. The results from this study indicate that ethyl acetate extract of $C$. cupreum exhibited antitumor activity against EAC cells and can be a candidate drug for screening in an animal model.

\section{Conclusion}

The evaluation of in vivo anticancer activity of ethyl acetate extract of $C$. cupreum displayed significant anticancer activity against EAC cells in treated animals. In this study, the work was aimed to explore the toxicity study and the anticancer activity of $C$. cupreum extract. In this study, analyses of blood parameters, biochemical parameters, enzymatic antioxidants, and marker of oxidative stress were examined at the tolerated concentrations of 50, 100, $200 \mathrm{mg} / \mathrm{kg}$ bwt in the control and experimental animals, respectively. The results showed that treatment with ethyl acetate extract of $C$. cupreum inhibited anticancer activity in a dose-dependent manner but reactive oxygen species in an independent manner against EAC cells. The results showed that $C$. cupreum extracts contain potent phytochemicals that can be used for therapeutic application after their purification and characterization.

\section{Acknowledgements}

The authors are grateful to the Head, Department of Microbiology and Biotechnology (MB \& BT), Bangalore University, Bengaluru (BUB), Karnataka, India, for the use of laboratory facilities.

Funding: The authors are grateful to UGC (University Grants Commission), New Delhi, Govt. of India, for UGC-MRP Grants (No-43-474/2014-SR) for financial support.

Author contributions: N.A.W. carried out all the assays, analysis, and interpretation of results, and wrote the initial manuscript. N.A.W. was responsible for the idea of research and interpretation of the results and edited the manuscript.

\section{Conflicts of interest}

There are no conflicts of interest.

\section{References}

1 Gerl R, Vaux DL. Apoptosis in the development and treatment of cancer. Carcinogenesis 2005; 26:263-270.

2 Karthikeyan R, Karthigayan S, Balasubashi MS. Antitumor effect of snake venom (Hydrophis spiralis) on Ehrlich ascites carcinoma bearing mice. Int $J$ Cancer Res 2007; 3:167-173.

3 Cragg GM, Newman DJ. Plants as a source of anticancer agents. J Ethnopharmacol 2005; 100:72-79. 
4 Harvey A. Natural products in drug discovery. Drug Discov Today 2008; 13:894-901.

5 Beta T, Nam S, Dexter JE, Sapirstein HD. Phenolic content and antioxidant activity of pearled wheat and roller-milled fractions. Cereal Chem 2005; 82:390-393.

6 Marinova D, Ribarova F, Atanassova M. Total phenolics and total flavonoids in Bulgarian fruits and vegetables. J Univ Chem Technol Metall 2005; 40:255-260.

7 Cragg GM, Kingston D, Newman DJ. Anticancer agents from natural products. London: Brunner-Routledge Psychology Press; 2005. 186-205.

8 Newman DJ, Cragg GM, Snader KM. Natural products as a source of new drugs over the period 1981-2002. J Nat Prod 2003; 66:1022-1037.

9 Sharpe PC, Richardson DR, Kalinowski DS, Bernhardt PV. Synthetic and natural products as iron chelators. Curr Top Med Chem 2011; 11:591-607.

10 Keller NP, Turner G, Bennett JW. Bennett. Fungal secondary metabolism - from biochemistry to genomics. Nat Rev Microbiol 2005; 3:937-947.

11 Wang XW. Systematic studies on Chaetomium Kunze and its morphologically simialr taxa from China [PhD thesis]. Beijing, China: Institute of Microbiology, Chinese Academy of Sciences, 2005.

12 Ames LM. New cellulose destroying fungi isolated from military material and equipment. Mycologia 1949; 41:637-648.

13 Natcha P, Somdej K, Kwanjai K, Soytong K. Chemical constituents from the fungus Chaetomium cupreum RY202. Arch Pharm Res 2015; 38:585-590.

14 Han X, Shen T, Lou H. Dietry polyphenols and their biological significance. Int J Mol Sci 2007; 8:950-988.

15 Dolai N, Karmakar I, Kumar RBS. Evaluation of antitumor activity and in vivo antioxidant status of Anthocephalus cadamba on Ehrlich ascites carcinoma treated mice. J Ethnopharmacol 2012a; 142:865-870.

16 Haldar PK, Kar B, Bala A. Antitumor activity of Sansevieria roxburghiana rhizome against Ehrlich ascites carcinoma in mice. Pharm Biol 2010; 48:1337-1343.

17 Nazir AW, Waseem IK, Sharmila T. Phytochemical analysis and evaluation of antibacterial activity of different extracts of soil-isolated fungus Chaetomium cupreum. J Nat Sci Biol Med 2020; 11:72-80.

18 Organization for Economic Cooperation and Development (OECD) guidelines for acute toxicity of chemicals. No. 425 (Adopted: 3 October 2008).

19 Jagetia GC, Baliga MS, Aruna R, Rajanikant GK, Jain V. Effect of abana (a herbal preparation) on the radiation-induced mortality in mice. $J$ Ethnopharmacol 2003; 86:159-165.

20 Davidson I, Henry JB. Todd-Sanford clinical diagnosis by laboratory methods. 14th ed. Philadelphia, London, Toronto: W.B. Saunders Co. 1969. 139-143

21 Sahli AF. Determination of haemoglobin by acid haematin method. In: Dacie JV, Lewis SM editors. Practical haematology. 5th ed. London: Churuchill; 1962.

22 Reitman S, Frankel S. A colorimetric method for determination of serum glutamate oxaloacetate and glutamic pyruvate transaminase. Am J Clin Pathol 1957; 28:56-58.

23 King J. The hydrolases-acid and alkaline phosphatises. In: practical clinical enzymology. London: Nostrand Company Pvt Ltd; 1965.

24 Allain CC, Poon LS, Chan CS, Richmond W, Fu PC. Enzymatic determination of total serum cholesterol. Clin Chem 1974; 20:470-475.
25 Werner M, Gabrielson DG, Eastman JU. Itramicro determination of serum triglycerides by bioluminescent assay. Clin Chem 1981; 27:268-271.

26 Misra HP, Fridovich I. The role of superoxide anion in the autoxidation of epinephrine and a simple assay for superoxide dismutase. J Biol Chem 1972; 247:3170-3175.

27 Aebi H. Catalase in vitro. Meth Enzymol 1984; 105:121-126.

28 Ellman GL, Fiches FT. Quantitative determination of peptides by sulfhydryl groups. Arch Biochem Biophys 1959; 82:70-72.

29 Hafemann DG, Sunde RA, Houestra WG. Effect of dietary selenium on erythrocyte and liver glutathione peroxidase in the rat. J Nutr 1974; 104:580-584.

30 Draper HH, Hadley M. Malondialdehyde determination as index of lipid peroxidation. Method Enzymol 1990; 86:421-431.

31 Wani NA, Tirumale S. Evaluation of antioxidant properties of different extracts of Chaetomium cupreum SS02. Bull Fac Pharma 2018; 56:191-198.

32 Adeyemo OK, Okwilagwe OO, Ajani F. Comparative assessment of sodium EDTA and heparin as anticoagulants for the evaluation of haematological parameters in cultured and feral African cathfish (Clariasgariepinus). Braz $\mathrm{J}$ Aquatic Sci Technol 2009; 13:19-24.

33 Schumann G, Klauke R. New IFCC reference procedures for the determination of catalytic activity concentrations of five enzymes in serum: preliminary upper reference limits obtained in hospitalized subjects. Clin Chim Acta 2003; 327:69-79.

34 Lustig V, Diamandis AP, Goldberg DM. Evaluation of commercially formulated aspartate aminotransferase and alanine aminotransferase activity determinations by the scandinavian committee on enzymes and IFCC methods as modified for use with automated enzyme analysers. Clin Biochem 1988; 21:283-290.

35 Gella FJ, Olivella T, Pastor MC, Arenas J, Moreno R, Durban R, Gomez JA. A simple procedure for the routine determination of aspartate aminotransferase and alanine aminotransferase with pyridoxal phosphate. Clin Chim Acta 1985; 153:241-247.

36 Storey KB. Oxidative stress: animal adaptation in nature. Braz J Med Res 1996; 29:1715-1733.

37 Droge W. Free radicals in the physiological control of cell function. Physiol Rev 2002; 82:47-95.

38 Haldar PK, Bhattacharya S, Dewanjee S, Majumder UK. Chemopreventive efficacy of Wedeliacaledulaceae against 20methylcholanthrene-induced carcinogenesis in mice. Environ Toxicol Pharmacol 2011; 31:10-15

39 Dahiru D, Obidoa O. Evaluation of the antioxidant effects of ziziphusmauritianalam: Leaf extracts against chronic ethanol-induced hepatotoxicity in rat liver. Afr J Trad Complement Altern Med 2008; 5:9-45.

$40 \mathrm{McCord} \mathrm{JM}$. The evolution of free radicals and oxidative stress. Am J Med 2000; 108:652-659.

41 Owen JB, Butterfield DA. Measurement of oxidized/reduced glutathione ratio. Methods Mol Biol 2010; 648:269-277.

42 Esterbauer H, Schaur RJ, Zollner H. Chemistry and biochemistry of 4hydroxynonenal, malonaldehyde and related aldehydes. Free Radical Biol Med 1991; 11:81-128.

43 Cirak B, Inci S, Palaoglu S, Bertan V. Lipid peroxidation in cerebral tumors. Clin Chim Acta 2003; 327:103-107. 